\title{
Due Process Limits on State Estate Taxation: An Analogy to the State Corporate Income Tax
}

The litigation between California and Texas as to which state should be able to levy an estate tax on Howard Hughes' intangible property ${ }^{1}$ brings to the forefront once again an old multiple taxation problem arising out of the United States federal structure. The U.S. Supreme Court has limited multiple taxation of estates by recognizing that the due process clause of the Fourteenth Amendment ${ }^{2}$ requires that real estate ${ }^{3}$ or tangible

1. The intangible property at stake was Summa Corporation stock owned by Howard Hughes at the time of his death. Though initially rumored to be worth more than a billion dollars, the stock was eventually valued at nearly three hundred and seventy million dollars. Litigation began in 1978, when the U.S. Supreme Court denied California's motion for leave to file a complaint under the Court's original jurisdiction. California v. Texas I, 437 U.S. 601 (1978). Although the denial was handed down without explanation in a per curiam decision, four concurring Justices suggested that jurisdiction had been denied on the grounds that there was no justiciable case or controversy. Id. at 601-02 (Brennan, J., concurring); id. at 614-15 (Stewart, J., joined by Powell \& Stevens, JJ., concurring). These Justices further suggested that a remedy might be found by filing an interpleader action in a federal district court. Id. at 601 (Brennan, J., concurring); id. at 608-09 n.10 (Stewart, J., joined by Powell \& Stevens, JJ., concurring); id. at 615-16 (Powell, J., concurring). A Texas district court dismissed a subsequent interpleader action because of lack of diversity. Lummis v. White, $491 \mathrm{~F}$. Supp. 5 (W.D. Tex. 1979), rev'd, 629 F.2d 397 (5th Cir. 1980). For a discussion of the lower court case history, see infra text accompanying notes $39-49$ and note 49 . In 1982, the Supreme Court reversed again, holding that the Eleventh Amendment does bar a statutory interpleader action in a federal district court. Cory v. White, 457 U.S. 85 (1982) (White, J., joined by Burger, C.J., and Blackmun, Rehnquist, \& O'Connor, JJ.). Justice Brennan concurred, but only on the grounds that as long as no constitutional violation could be alleged, a remedy would have to be allowed under the Court's original jurisdiction. Brennan also suggested that he agreed with Justice Powell's arguments that a due process violation could be alleged. Id. at 92 . Justice Powell wrote a strong dissenting opinion in which Justices Marshall and Stevens joined, arguing that since the suit under the Court's original jurisdiction was not ripe, a remedy should not be sought there, but rather the Court should recognize that due process does prohibit double taxation of decedent's estates, and that at any rate a remedy to a problem caused by the federal structure of the United States should be available. Id. at 94, 98-101. Since no other remedy was available, the Court deemed the dispute between the states justiciable as an action in the nature of an interpleader, and simultaneously granted California's renewed motion for leave to file a complaint against Texas under the Court's original jurisdiction. California v. Texas II, 457 U.S. 164 (1982) (per curiam). Justice Powell issued a dissent declaring that the suit was unripe. Id. at 169-71 (Powell, J., joined by Marshall, Rehnquist, \& Stevens, JJ., dissenting). Shortly thereafter, the Supreme Court appointed a Special Master, who subsequently arranged a settlement of the case. According to one newspaper account, both states have agreed to split the estate tax. No finding of domicile was made. Rather, the Hughes estate will pay 50 million dollars in cash to Texas. California will receive 44 million dollars in cash, along with 70 acres of prime real estate adjacent to the Hughes airstrip west of Los Angeles. California waived its right to claim domicile. N.Y. Times, July 7,1984 , at A6, col. 1.

2. U.S. CoNST. amend. XIV, § 1.

3. The notion that real property may be taxed only by the state within which the property is located - the state of situs-is rooted in ancient common law. For representative Supreme Court cases that discuss and elevate the notion to a principle of constitutional law, see Union Refrigerator Transit Co. v. Kentucky, 199 U.S. 194, 202-03 (1905) ("The power of taxation . . . is exercised upon the assumption of an equivalent rendered to the taxpayer in the protection of his person and property 
personal property ${ }^{4}$ be subject to an estate tax only in the state where the property is physically located at the time of death-the state of situs. ${ }^{5}$ Since real estate and tangible property are physically present in only one place at a time, estates comprised of these types of assets are not threatened by multiple taxation. ${ }^{6}$

Intangible property, such as stocks and bonds, however, is by nature siteless. ${ }^{7}$ Therefore, another means to trigger state sovereign taxing powers must be used. The states have chosen to use the state of the decedent's domicile, ${ }^{8}$ rather than the state of situs, to levy an estate tax on intangible property. Although all states but one agree that a person may have only

.... If the taxing power be in no position to render these services . . . [because] such property be wholly within the taxing power of another State . . . to which it looks for protection . . . [the taxation by the domiciliary state amounts.to] a taking of property without due process of law."); State Tax on Foreign-held Bonds, 82 U.S. (15 Wall.) 300,319 (1872) (taxing power of state limited to persons, property and businesses within its jurisdiction); McCulloch v. Maryland, 17 U.S. (4 Wheat.) 316 , 429 (1819) ("All subjects over which the sovereign power of a State extends, are objects of taxation; but those over which it does not extend, are, upon the soundest principles, exempt from taxation."); see also Senior v. Braden, 295 U.S. 422,429 (1935) (real estate taxable only by the state in which the real estate is located).

4. Tangible personal property, like real property, is taxable only by the state of situs. See Union Refrigerator, 199 U.S. at 204 (extending same protection from multiple taxation accorded real property to tangible personal property); Frick v. Pennsylvania, 268 U.S. 473, 488-92 (1925) (extending Union Refrigerator rationale governing taxation of property to taxation of estates; even though estate tax is levied on succession of property, rather than on property itself, state must still have jurisdiction over property to levy estate tax); see also Curry v. McCanless, 307 U.S. 357, 364 (1939) ("The power of government and its agencies to possess and to exclude others from possessing tangibles, and thus to exclude them from enjoying rights in tangibles located within its territory, affords adequate basis for an exclusive taxing jurisdiction."); City Bank Farmers Trust Co. v. Schnader, 293 U.S. 112, 118 (1934) (taxability of tangible personalty determined by situs, regardless of decedent's domicile). But see Bittker, The Taxation of Out-of-State Tangible Property, 56 YAlE L.J. 640 (1947) discussed infra note 61 (suggesting that tangibles should not be treated the same as real property).

5. For two interesting analyses arguing that the sole function of the concept of situs is to prevent double taxation, see Brown, Multiple Taxation by the States-What Is Left of It?, 48 HARv. L. REv. 407, 408-09 (1935); Lowndes, Spurious Conceptions of the Constitutional Law of Taxation, 47 HARv. L. REv. 628, 630-39 (1934).

6. If there is a dispute as to the situs of the property, the claiming states or the threatened estate may request Supreme Court review of the conflicting state court judgments. See Thomas v. Virginia, 364 U.S. 443 (1960) (per curiam) (due process prohibits state inheritance tax on tangible property outside that state); Treichler v. Wisconsin, 338 U.S. 251 (1949) (same).

7. Greenough v. Tax Assessors, 331 U.S. 486, 493 (1947) (distinguishing tangible property from intangible property and declaring that there is no method of determining where intangibles are situated); State Tax Comm'n v. Aldrich, 316 U.S. 174, 178 (1942) (same); Union Refrigerator, 199 U.S. at 205 (same).

8. Domicile is defined as:

That place where a man has his true, fixed, and permanent home and principal establishment, and to which whenever he is absent he has the intention of returning .... A person may have more than one residence but only one domicile. The legal domicile of a person is important since it, rather than the actual residence, often controls the jurisdiction of the taxing authorities ....

Black's Law Dictionary 435 (5th ed. 1979). Once a person acquires a domicile, he or she retains that domicile until he or she acquires a new one. There are three types of domicile: (1) the domicile of origin, which is the place where one is born; (2) the domicile of choice, which a person of requisite legal capacity acquires by physical presence and the intent to remain indefinitely; (3) the domicile fixed by the operation of law usually concerning the domicile of children and incompetents. RESTATEMENT (Second) of Conflict of Laws $\$ \S 11-23$ (1971). The actual legal definition of domicile 
one domicile at a time, ${ }^{\circ}$ occasionally, as in the Howard Hughes case, more than one state claims that the deceased was domiciled within its borders. ${ }^{10}$ Unlike situs, however, use of the state common law concept of domicile for the purpose of determining jurisdiction to levy an estate tax is considered unreviewable in either the lower federal courts or the United States Supreme Court. ${ }^{11}$ There are no established constitutional ${ }^{12}$ bars to protect the intangible estate from multiple taxation. The estate must pay each state its claimed tax. ${ }^{13}$

Justice Powell recently argued that the multiple taxation of an estate by more than one state on the basis of domicile violates the due process clause of the Fourteenth Amendment. ${ }^{14}$ This Note suggests that, although Justice Powell's specific suggestion as to how the due process analysis could be used to provide a remedy is not feasible, the due process limits on state power in the corporate taxation area offer a persuasive analogy for the recognition of due process limits on state power to tax intangible estates. ${ }^{18}$ Once these principles are recognized, estate administrators would be able to seek a remedy in the Supreme Court to review the judgments rendered by state courts. The application of these due process limits on state power

varies from one state to the next. See infra text accompanying notes 30-31. Two articles which discuss some of the mechanics of how domicile is determined and the various technical problems from a practitioner's point of view are Guterman, Avoidance of Double Death Taxation of Estates and Trusts, 95 U. PA. L. REv. 701, 703-08 (1947); Marsh, Multiple Death Taxation in the United States, 8 UCLA L. REv. 69, 79-87 (1961).

9. Only North Carolina does not grant any sort of exemption to ensure that only the one state of domicile levies an estate tax, see discussion infra note 25.

10. One example of the complicated litigation which ensues when two states attempt to tax the same intangible estate is set forth in the In re Dorrance's Estate litigation: In re Dorrance's Estate, $309 \mathrm{~Pa} .151,163$ A. 303, cert. denied, 287 U.S. 660 (1932) (federal question not properly presented to, or passed upon by Pennsylvania Supreme Court); In re Dorrance's Estate, 172 A. 900 (Pa. 1932) (decision reaffirmed), cert. denied, 288 U.S. 617 (1932); New Jersey v. Pennsylvania, 287 U.S. 580 (1932) (motion for leave to file complaint under Court's original jurisdiction denied); Pennsylvania v. New Jersey, 288 U.S. 618 (1933) (same); Dorrance v. Martin, 12 F. Supp. 746 (D.N.J.) (attempt to enjoin collection of New Jersey's assessment dismissed on grounds that federal jurisdiction was lacking), aff'd sub nom. Hill v. Martin, 296 U.S. 393 (1935); In re Dorrance's Estate, 113 N.J. Eq. 266, 166 A. 177 (Prerog. Ct. 1933), aff'd, 115 N.J. Eq. 268, 170 A. 601 (Prerog. Ct.), supplemented by, 116 N.J. Eq. 204, 172 A. 503 (Prerog. Ct. 1934), aff'd sub nom. Dorrance v. Thayer-Martin, 13 N.J. Misc. 168, 176 A. 902 (1935), aff'd, 116 N.J.L. 362, 184 A. 743, cert. denied, 298 U.S. 678 (1936) (ultimately both states permitted to levy estate tax on Campbell Soup fortune left by Mr. Dorrance).

11. See Worcester County Trust Co. v. Riley, 302 U.S. 292 (1937).

12. There was a constitutional prohibition against such multiple taxation of intangible estates, Farmers Loan Co. v. Minnesota, 280 U.S. 204 (1930), but it has been overruled by State Tax Comm'n v. Aldrich, 316 U.S. 174 (1942). See infra note 18.

13. See Massachusetts v. Missouri, 308 U.S. 1, 15-16 (1939); Worcester County Trust Co. v. Riley, 302 U.S. 292, 299 (1937).

14. Cory v. White, 457 U.S. 85, 92-101 (1982) (Powell, J., joined by Marshall \& Stevens, JJ., dissenting).

15. The due process limits in the state corporate tax area comport with the recent developments in due process analysis in other areas, such as choice of law and adjudicative jurisdiction. See infra text accompanying notes $61-66$ \& note 65 . 
to tax intangibles would add a coherence sorely lacking in the due process analysis currently used in state estate taxation.

\section{The Failure of an Analogr: Due Process Limits Break Down}

The series of cases prior to 1942 which established due process limits on estate taxation of real estate, tangibles, and intangibles were based on a somewhat mechanical extension of the ancient doctrine of situs. ${ }^{16}$ In 1942 the Supreme Court found that the logic behind the doctrine of situs, so far removed from its original field of application, could not justify similar due process limits on intangible property. ${ }^{17}$ Ending twelve years of confusion and indecision, ${ }^{18}$ the Court declared in State Tax Comm'n v. Aldrich ${ }^{18}$ that because the estate tax is a tax on the transfer of property from the dead to the living, any state which facilitates that transfer has a taxable

16. See supra notes $3,4,5 \& 7$ which trace the evolution of due process limits on real and tangible property alongside the distinctions the Court has drawn regarding intangibles.

17. State Tax Comm'n v. Aldrich, 316 U.S. 174 (1942).

18. Prior to 1929 , there was no prohibition on the multiple taxation of intangibles, Blackstone v. Miller, 188 U.S. 189 (1903). Succession was a privilege granted, and therefore taxable, by the state of domicile and any other state whose laws facilitated the succession. Id. at 204-05. However, as intangible property became more important, and tangible property was granted the same immunity from multiple taxation as real property, Frick v. Pennsylvania, 268 U.S. 473, 488-92 (1925), the Court felt compelled to overrule Blackstone and grant intangible property a similar immunity from multiple taxation despite the lack of an ascertainable situs. In Farmers Loan Co. v. Minnesota, 280 U.S. 204 (1930), the Court held that state bonds and municipal certificates of indebtedness were taxable only by the state of domicile, declaring that:

We have determined that in general intangibles may be properly taxed at the domicile of their owner and we can find no sufficient reason for saying that they are not entitled to enjoy an immunity against taxation at more than one place similar to that accorded to tangibles. The difference between the two things, although obvious enough, seems insufficient to justify the harsh and oppressive discrimination against intangibles . . . .

Id. at 212. A rapid succession of cases followed, extending immunity from multiple taxation to other forms of intangible property: Baldwin v. Missouri, 281 U.S. 586 (1930) (bank deposits, promissory notes and bonds); Beidler v. South Carolina Tax Comm'n, 282 U.S. 1 (1930) (indebtedness for advances and unpaid dividends); First Nat'l Bank v. Maine, 284 U.S. 312 (1932) (corporate stock).

Within a few years, however, the Court began its retreat from the Farmers Loan position. Graves v. Elliott, 307 U.S. 383 (1939) (permitting taxation of trust property by both state of domicile and state of administration); Curry v. McCanless, 307 U.S. 357 (1939) (same). In 1942, the Court returned to its original rule, permitting states to levy taxes on the basis of different benefits conferred, stating:

[E]ven though we believed that a different system should be designed to protect against multi-

ple taxation, it is not our province to provide it ... . To do so would be to indulge in the dangerous assumption that the Fourteenth Amendment was "intended to give us carte blanche to embody our economic or moral beliefs in its prohibitions."

State Tax Comm'n v. Aldrich, 316 U.S. 174, 181 (1942) (citations omitted). For a more thorough history and discussion of these doctrinal shifts caused by the Supreme Court's attempts to eliminate multiple taxation of intangibles, see Brown, The Present Status of Multiple Taxation of Intangible Property, 40 Mich. L. REv. 806 (1942); Guterman, Revitalization of Multiple State Death Taxation, 42 Colum. L. Rev. 1249 (1942); Merrill, Jurisdiction to Tax-Another Word, 44 YALE L.J. 582 (1935); Morton \& Cotton, Limitations on State Jurisdiction to Levy Death Taxes, 5 Miami L.Q. 449 (1951); Nash, And Again Multiple Taxation?, 26 GEo. L.J. 288 (1938).

19. 316 U.S. 174 (1942). 
relationship to succession. ${ }^{20}$ Thus if the intangible estate consists of corporate stock, the decedent's state of domicile, ${ }^{21}$ the state in which the stock certificates are kept in a bank safety vault, ${ }^{22}$ the state of corporate domicile, ${ }^{23}$ and any other state conferring some benefit, ${ }^{\mathbf{2 4}}$ may levy an estate tax, since each has facilitated the transfer of the corporate stock. The states, however, have not chosen to do so: Of the forty-nine states that levy an estate tax, forty-eight have effectively declared that only the state of domicile may levy an estate tax. ${ }^{25}$ The state legislatures have essentially

\section{The Aldrich Court declared:}

[W] repeat that there is no constitutional rule of immunity from taxation of intangibles by more than one State. In case of shares of stock, "jurisdiction to tax" is not restricted to the domiciliary State. Another State which has extended benefits or protection, or which can demonstrate "the practical fact of its power" or sovereignty as respects the shares . . . may likewise constitutionally make its exaction. In other words, we restore these intangibles to the constitutional status which they occupied up to a few years ago.

State Tax Comm'n v. Aldrich, 316 U.S. 174, 181-82 (1942) (citations omitted).

21. Id.

22. See Curry v. McCanless, 307 U.S. 357, 360-61, 370 (1939).

23. See State Tax Comm'n v. Aldrich, 316 U.S. at 178.

24. In his dissent to State Tax Comm'n v. Aldrich, Justice Jackson protested the looseness of such a benefits-conferred rationale:

My difficulty is that on its face-and as so far applied-this test comes out to the point where might does make right. For in a very real sense every State and Territory in the Union has conferred very real benefits upon every inhabitant of the Union. Some States have seen to it that our food is properly produced .... All of them have yielded up men to provide government at home and to repel the enemy abroad. I am the very real debtor, but am frank enough to say I hope not a potential taxpayer, of all.

Id. at 200.

25. Eighteen states provide complete immunity from estate taxes for intangibles owned by a nonresident decedent. InHer. Est. \& GifT TAX REP. (CCH) II 12,080 (Nov. 1970); Note, Problematic Definitions of Property in Multistate Death Taxation, 90 HARv. L. Rev. 1656, 1664 (1977) [hereinafter referred to as Note, Problematic Definitions]. Seventeen other states have adopted the provisions of the UNIF. Reciprocal Transfer TAX ACT, 7A U.L.A. 317 (Supp. 1928) exempting intangibles owned by a nonresident if his or her domicile either does not tax the intangibles of nonresidents, or providing an exemption whenever the decedent's domicile provides a reciprocal exemption. Note, Problematic Definitions, supra, at 1664. An additional 13 states grant partial exemptions to foreignheld intangibles. Id. at 1664-65. Only North Carolina does not grant an exemption for a nonresident's intangibles. Id. at 1665 n.58. Nevada does not even levy an estate tax. NEv. ConsT. art. 10, $\$ 1$. For another discussion of the exemptions and the citations of the relevant statutes, see Survey of State Death Tax Systems and of Selected Problems of Double Taxation of Real Property Interests, 14 Real Property, Probate, and Trust J. 277, 287 apps. A \& B (1979) (listing relevant state statutes) [hereinafter referred to as Survey].

State legislatures have also attempted to solve the problem by adopting arbitration or compromise acts. See UnIf. Interstate Compromise of Death TaXes Act, 8A U.L.A. 535 (1943) (empowering tax officials of claiming states to negotiate state's share of taxes); UNIF. INTERSTATE ARBITRATION OF DeATH TAXes ACT, 8A U.L.A. 521 (1943) (empowering arbitration board to make binding determination of domicile). Many states have not adopted either of these schemes, however, and even among those states which have, the schemes may not be mandatory. As a result, concerned parties must look to judicial intervention. Note, Double Domicile and Federal Interpleader Revisited, $33 \mathrm{Sw}$. L.]. 1241, 1244 (1980) [hereinafter referred to as Note, Double Domicile]. For other discussions of these various provisions, see Freedman, Practical Aspects of Multiple State Taxation of Intangibles of NonResident Decedents Since the Aldrich Case, 24 Notre Dame Law. 41, 41-59 (1948); Guterman, supra note 18, at 1279-80; INHER. EsT. \& GiFT TAX REP. (CCH) I 12,035 (March 1975). 
eliminated the problem of multiple taxation caused by the differing benefits which states may confer upon the succession of intangible estates. ${ }^{28}$

The problem of multiple findings of domicile, however, remains unaddressed and unsolved. As Justice Powell recently declared, it seems inherently illogical to uphold multiple taxation on the basis of domicile when each of the claiming states would agree that only the state of domicile may levy an estate tax and that a person may have only one domicile at the time of death. ${ }^{27}$ Since a person may have only one domicile at a time, one of the states levying the estate tax necessarily lacks domicile. The state that lacks domicile lacks the nexus required by the due process clause. ${ }^{28}$ The same state has also levied the tax without the authority of its own state law. Such a violation of state law, in and of itself, constitutes a due process violation. ${ }^{2 \theta}$

The difficulty with this reasoning is that it presumes not only that the disputing states agree that a person may have only one domicile at a time and that only the state of domicile may levy a tax ${ }^{30}$ but also that each of the states has defined domicile in precisely the same way in its case law and has given the exact same evidentiary weight to the various factors and

26. When one state declares a decedent's property intangible and another declares the same property tangible personalty, however, the difference in characterization can lead either to double taxation or to no taxation at all. See Note, Problematic Definitions, supra note 25, at 1665-70; Survey, supra note 25 , at $277-86$.

27. See Cory v. White, 457 U.S. 85, 99-100 (1982) (Powell, J., dissenting).

28. Id.

29. Although states are not bound by the laws of other states, states are bound by their own laws. See infra text accompanying notes 27-39. If a state violates its own law, that constitutes a due process violation, Ex parte Young, 209 U.S. 123 (1908), which gives rise to federal question jurisdiction. Although in this particular situation the Tax Injunction Act bars federal court jurisdiction, see infra note 87 , the federal question does give rise to Supreme Court review. If the state supreme court finds that a decedent was domiciled within its borders when controlling precedent indicates that the court should have found otherwise, the estate administrators are not without remedy. Even though state supreme courts are normally the final authorities on matters of state law, the U. S. Supreme Court will review state law matters to prevent the independent and adequate state ground doctrine from either trumping Supreme Court jurisdiction or nullifying a constitutional right. See Aloha Airlines v. Director of Taxation, 104 S. Ct. 291 (1983); Evans v. Newton, 382 U.S. 296 (1966); Ward v. Board of County Comm'rs, 253 U.S. 17 (1920). Allowing a state to determine that a person was domiciled within the state at the time of death, despite contrary state precedent, would trivialize the due process limits on state taxing power. It is rather surprising that no one has attempted to make this type of claim. The record in the Hughes cases suggests that the Hughes estate administrators could have made a good case that, in declaring that Hughes was domiciled within its borders, Texas violated its own law. See discussion infra notes 89-91.

30. Of course, if the claiming states do not agree that only the state of domicile may levy an estate tax or that a person may have only one domicile at a time, then Justice Powell's argument fails completely. One state could claim the tax on the basis of corporate domicile, and the other state would claim the tax on the basis of the decedent's domicile. Each state could also claim the tax on the same basis of domicile. 
presumptions considered to determine domicile. Yet a prominent characteristic of common law is that case law rarely, if ever, develops in precisely the same way among different courts and different states. As a result, it is entirely possible for a court to find domicile pursuant to its own state law, although that finding may not be consistent with another state's law. States are not bound by the laws of other states except as dictated by the full faith and credit clause. ${ }^{31}$ As the Howard Hughes case illustrates, there is almost never a single, determinate forum for multiple taxation of intangible estates when two or more states assert that the decedent was domiciled within their respective borders at the time of death. Our federal structure precludes a remedy. ${ }^{32}$

\section{Falling Through the Interstices of the Federal STRUCTURE}

\section{A. The Inadequacy of State Court Remedies}

Because domicile is a state common law concept, the determination as to where a decedent is domiciled must be made in a state court according to state law. If the estate administrators bring suit in a Texas state court alleging that the decedent was domiciled only in Texas, the Texas court cannot render a judgment binding on the state of Galifornia. The sovereign immunity doctrine ${ }^{33}$ protects California from being haled into a

31. See infra text accompanying notes 35-38.

32. Justice Powell explicitly acknowledged the uniquely federal cause of the multiple taxation problem: "It is our federal system which creates the possibility of double taxation. Somewhere within that federal system we should be able to find remedies for the frictions which that system creates." California v. Texas I, 437 U.S. 601, 616 (1978) (Powell, J., concurring) (quoting Chafee, Federal Interpleader Since the Act of 1936, 49 YALE L.J. 377, 388 (1940)). Justice Brennan also expressed such a concern: "I agree with Professor Chafee . . . that "[s]omewhere within [the] federal system we should be able to find remedies for the frictions which that system creates." Cory v. White, 457 U.S. 85, 92 (1982). In his dissent from the latter opinion, Justice Powell again stressed his concern that there be a federal solution to a federal problem: "Thus, at least in a case such as this, in which the very controversy is the result of our federal system, I continue to believe that resort to federal interpleader is not proscribed by the Eleventh Amendment as construed by Edelman v. Jordan." Id. at 96 (Powell, J., dissenting).

33. Sovereign immunity is an ancient common law concept rooted in English feudalism. Though some historians have claimed that the concept is an accident of history, see 1 F. Pollock \& F. MAITLAND, History of ENGLiSh LAW 511-18 (2d ed. 1899), ensuring the sovereign immunity of the states was clearly a major concern during the Constitutional Convention:

It is inherent in the nature of sovereignty, not to be amenable to the suit of an individual without its consent. This is the general sense and the general practice of mankind; and the exemption, as one of the attributes of sovereignty, is now enjoyed by the government of every State in the Union. Unless, therefore, there is a surrender of this immunity in the plan of the convention, it will remain with the States ....

The Federalist No. 81, at 487-88 (A. Hamilton) (C. Rossiter ed. 1961). Sovereign immunity was not an explicit part of the Constitution, however, until the enactment of the Eleventh Amendment, which addresses sovereign immunity with respect to federal courts but not state courts. Nonetheless the Court has often implicitly, and sometimes explicitly, recognized such immunity in other state courts. See, e.g., Western Union Tel. Co. v. Pennsylvania, 368 U.S. 71, 75, 80 (1961) (Pennsylvania 
Texas court as long as California has not somehow entered Texas territory, subjecting itself to Texas sovereignty. ${ }^{34}$ If the Texas court hands down a judgment without California as a party to the litigation, that judgment will not necessarily be res judicata in any subsequent suits brought in California courts. ${ }^{35}$ Whenever a judgment of a state court is asserted to be res judicata in another state court's proceeding, the adjudicative jurisdiction of the rendering court is subject to inquiry; if it appears that the rendering court did not have adjudicative jurisdiction, its judgment is not entitled to full faith and credit. ${ }^{36}$

In the area of estate taxation, only the state in which the decedent was domiciled has adjudicative jurisdiction. ${ }^{37}$ Therefore, California may simply ignore the Texas judgment by declaring that the decedent was domiciled in California, not Texas, and that the Texas court did not have jurisdiction to render a judgment. Texas may, of course, do the same if suit is originally brought in a California state court. Only if one state is willing to appear and be bound by the decision of the opposing state will the resulting judgment protect the estate from double taxation. Not surprisingly, states have often been unwilling to waive their sovereign immunity in another state's court, particularly when the disputed estate taxes involve a large sum of money. ${ }^{38}$

court's inability to assert jurisdiction over New York taxing authorities to prevent double escheat of intangible property threatened due process violation). In reaching its holding, the Court declared: "It is plain that Pennsylvania courts, with no power to bring other States before them, cannot give such hearings." Id. at 80. See also Principality of Monaco v. Mississippi, 292 U.S. 313 (1934). The Court explained:

Manifestly, we cannot rest with a mere literal application of the words of $\S 2$ of Article III, or assume that the letter of the Eleventh Amendment exhausts the restrictions upon suits against non-consenting States. Behind the words of the constitutional provisions are postulates which limit and control . . . . There is also the postulate that States of the Union, still possessing attributes of sovereignty, shall be immune from suits, without their consent . . .

Id. at 322. After the decision in Nevada v. Hall, 440 U.S. 410 (1979), discussed infra note 34, states may no longer possess such absolute immunity in other states' courts.

34. See Nevada v. Hall, 440 U.S. 410 (1979) (state sovereign immunity in other states' courts is not grounded in or compelled by the Constitution, but rather is a matter of comity between states). Justice Blackmun's dissent in Hall does suggest, though, that on the basis of a disclaimer in footnote 24 of the majority opinion, the holding should be limited to those circumstances where the state official has crossed over state borders and entered into the territory of another sovereign state. Thus in Hall, the Nevada state official lost his immunity because he had entered California territory. 440 U.S. at 428-32 (Blackmun, J., joined by Burger, C.J., \& Rehnquist, J., dissenting). Despite the majority's broad holding in $\mathrm{Hall}$, states probably will still feel compelled to grant other states sovereign immunity in their state courts, if only as a matter of comity.

35. Baker v. Baker, Eccles \& Co., 242 U.S. 394, 401-04 (1917) (in rem judgments as to domicile rendered in one state court not binding on another state's court); Tilt v. Kelsey, 207 U.S. 43, 59 (1907) (state court not bound by another state's adjudication of domicile if jurisdiction was lacking); Thormann v. Frame, 176 U.S. 350, 356 (1900) (court presented with claim of res judicata may inquire into jurisdiction of rendering court).

36. Burbank v. Ernst, 232 U.S. 162 (1914).

37. Nevin v. Martin, 22 F. Supp. 836, 839 (D.N.J. 1938), affd, 307 U.S. 615 (1939).

38. When a state has waived its sovereign immunity and agreed to appear as a party in another state's court, binding judgments of domicile have then been rendered. See, e.g., In re Bourne's Estate, 


\section{B. The Inadequacies of Lower Federal Court Remedies}

Federal courts do not have jurisdiction to resolve the multiple domicile question either. There is neither federal question jurisdiction, since domicile is a state law concept, nor diversity jurisdiction, since states cannot be citizens of themselves for the purpose of diversity. ${ }^{38}$ Additionally, the Eleventh Amendment bars suits against states in a federal court. ${ }^{40}$

The Federal Interpleader Act of $1936^{41}$ was enacted in part to remedy the adjudicative gap caused by the federal courts' limited jurisdiction. A federal question is no longer needed to bring a suit in a federal court if the adverse parties are diverse. Shortly after passage of the Act, in Worcestor County v. Riley, ${ }^{42}$ estate administrators sought to interplead the state taxing officials of Massachusetts and California to determine where the decedent had been domiciled. The Court found, however, that even though a federal question was no longer needed to bring the suit in federal court, the suit was still one forbidden by the Eleventh Amendment. ${ }^{43}$ The administrators had tried to bring their case within the scope of the $E x$ parte Young doctrine, ${ }^{44}$ arguing that the levy of the same estate tax by two states violated the due process clause. The suit, therefore, was not against the state but against the state taxing officials to prevent an unconstitutional extension of state power. The administrators argued that since the parties in interest-the state officials-were citizens of states for diversity purposes, the suit fell within the federal court's diversity jurisdiction. ${ }^{45}$

181 Misc. 238, 41 N.Y.S.2d 336 (Sur. Ct. 1943), aff'd, 267 A.D. 876, 47 N.Y.S.2d 134 (App. Div.), aff'd, 293 N.Y. 785, 58 N.E.2d 729 (1944); In re Benjamin's Estate, 176 Misc. 518, 27 N.Y.S.2d 948 (Sur. Ct. 1941), aff'd, 263 A.D. 981, 34 N.Y.S.2d 394 (App. Div.), aff'd, 289 N.Y. 554, 43 N.E.2d 531 (1942).

39. Postal Tel. Cable Co. v. Alabama, 155 U.S. 482, 487 (1894).

40. The Eleventh Amendment declares: "The Judicial power of the United States shall not be construed to extend to any suit in law or equity, commenced or prosecuted against one of the United States by Citizens of another State, or by Citizens or Subjects of any Foreign State." U.S. CoNST. amend. XI. Despite the amendment's literal language, the Court has construed the amendment to bar suits brought by citizens against their own states as well as against other states, and to bar even suits arising under the Constitution or the laws of the United States. Hans v. Louisiana, 134 U.S. 1, 10, 15 (1890).

41. Pub. L. No. 422, 49 Stat. 1096 (codified as amended at 28 U.S.C. $§ 1335$ (1982)). Congress passed the new Act to provide a federal forum for disputes where state courts lacking adjudicative jurisdiction over out-of-state parties consequently lacked the power to provide a remedy. The act permits a stakeholder holding an asset or assets claimed by two or more persons from differing states to join all the claimants in one suit. For a description of how the interpleader action might work, see Note, Double Domicile, supra note 25, at 1246 n.40 (1980).

42. 302 U.S. 292 (1937).

43. Id. at 299-300.

44. See Ex parte Young, 209 U.S. 123 (1908) (state officer's attempt to enforce unconstitutional statute constitutes proceeding without authority of state in its sovereign or governmental capacity, strips officer's actions of their official character, and subjects officer to consequences of his or her individual conduct).

45. There is some question as to whether Ex parte Young would distinguish the state officer from the state for the purposes of diversity jurisdiction. Some federal district courts have held that Ex parte Young does render the suit one against the state officer for diversity purposes. See Mouton v. Sinclair 
Surprisingly, despite its relatively recent holding that only one state, the state of domicile, could levy an estate tax, ${ }^{46}$ the Court refused to declare the double taxation unconstitutional. Instead, the Court held that because the Constitution does not require identical findings on issues of fact in the decisions of different state courts, each state's adjudication of domicile was valid. There had been no due process violation to render the suit one against the state officials for diversity purposes, or remove the Eleventh Amendment bar. ${ }^{47}$

The Eleventh Amendment has remained a fatal stumbling block. In the 1978 Howard -Hughes case, the Supreme Court suggested that Edelman v. Jordan ${ }^{48}$ had overruled Worcestor County's holding that the Eleventh Amendment bars a stakeholder from interpleading two states in a federal district court. ${ }^{49}$ Four years later, however, the Supreme Court rejected its

Oil \& Gas Co., 410 F.2d 717, 718 (5th Cir. 1969), cert. denied, 398 U.S. 957 (1970); Ohio ex rel. Seney v. Swift \& Co., 270 F. 141, 150 (6th Cir.), cert. denied, 257 U.S. 633 (1921), appeal dismissed, 260 U.S. 146 (1922); State Life Ins. Co. v. Daniel, 6 F. Supp. 1015, 1019 (W.D. Tex. 1934). Other federal courts have ruled to the contrary. See Nuclear Eng'g Co. v. Scott, 660 F.2d 241, 251 (7th Cir. 1981); Eure v. N.V.F. Co., 481 F. Supp. 639, 641 (E.D.N.C. 1979); National Mkt. Reports, Inc. v. Brown, 443 F. Supp. 1301, 1305 n.7 (S.D.W. Va. 1978). The Supreme Court has not ruled on the question.

46. First Nat'l Bank v. Maine, 284 U.S. 312 (1932).

47. Worcester County Trust Co. v. Riley, 302 U.S. 292, 299-300 (1937).

48. 415 U.S. 651 (1974) (Ex parte Young allows only prospective declaratory or injunctive relief, not retroactive payments from state treasuries, as remedy in suit brought against state officers for unconstitutional processing of welfare applications).

49. Four Justices espoused this view when concurring in California v. Texas I, 437 U.S. 601 (1978) (denying California's first motion for leave to file complaint under Court's original jurisdiction to resolve question of where Howard Hughes was domiciled at time of his death). The administrators of the Hughes estate subsequently filed an interpleader action in a federal district court in Texas. The district court judge dismissed without discussion the concurring Justices' view of Edelman, and instead relied on the holding in Worcestor County that no constitutional violation was involved. Lummis v. White, 491 F. Supp. 5, 9 (W.D. Tex. 1979). Reasoning that therefore the real parties at interest were the states, and that states cannot be citizens of themselves for the purposes of diversity, the judge dismissed the interpleader action as lacking diversity. Id. at 8. On appeal, the Fifth Circuit reversed. After discussing the extensive history of the Interpleader Act and the congressional intent that it be a flexible tool of equity, Lummis v. White, 629 F.2d 397, 399-400 (5th Cir. 1980), the court attempted to explain how Edelman $v$. Jordan had overruled, sub silentio, Worcester. County. The court of appeals reasoned that the remedy sought was not one which would have imposed a liability to be paid from public funds in the state treasury. Rather, it was a remedy which would have had "fiscal consequences to state treasuries . . . [only as] the necessary result of compliance with decrees which by their terms [are] prospective in nature." Id. at 401 (quoting Edelman v. Jordan, 415 U.S. at 667-68). The administrators were not, the court reasoned, suing for funds from the state treasury, but rather were seeking to prevent a future collection of money. And even then, the administrators sought not so much to prevent the collection of money as to obtain a single determination of domicile. Thus, the effect on the state treasury could be seen as ancillary to the remedy sought. Under this interpretation, the suit would not be barred by the Eleventh Amendment. Id. at 402 . Since the states were still the real parties in interest, however, the court of appeals was still forced to engage in some fairly elaborate and unorthodox jurisdictional gymnastics to find that the parties did satisfy the diversity requirements necessary to file an interpleader action in a federal court. The court found diversity by assuming that an interested stakeholder may be considered for purposes of establishing diversity under 28 U.S.C. $\$ 1335$. Id. at 403 . Since it had already been conceded that the acting county treasurer of Los Angeles County was a citizen of California for diversity purposes, $i d$. at 402 , there was diversity between two adverse parties-the interested Nevada stakeholder and the California treasurer. Id. at 
own suggestion, instead holding that Edelman had not so narrowed the scope of the Eleventh Amendment. ${ }^{80}$ The Court emphasized that the Eleventh Amendment gives way only when state officers "are alleged to be acting contrary to federal law or against the authority of state law." Since neither violation had been alleged, Worcestor County v. Riley was still a valid and controlling precedent. ${ }^{52}$

\section{The Supreme Court Remedy-Available Only at the Court's Discretion}

The only potential remedy for the dilemma caused by the multiple taxation of intangibles is for one state to sue the other state under the United States Supreme Court's original jurisdiction. ${ }^{53}$ Yet this remedy is tenuous. There must be a controversy between the states. As long as all the claiming states may collect the taxes levied, however, there is no dispute between the states. ${ }^{\text {.4 }}$

Only in the rare instance that there is not enough money in the estate to pay all the claimed taxes will the claiming states have a monetary interest in the litigation and become real parties in interest. The Supreme Court will then have jurisdiction over the controversy, but that jurisdiction is discretionary. The Supreme Court may refuse to hear the dispute. ${ }^{55}$

404.

50. Cory v. White, 457 U.S. 85,90 (1982).

51. Id. at $90-91$.

52. Id. at 91.

53. The landmark case which set the precedent for such suits under the original jurisdiction of the Supreme Court is Texas v. Florida, 306 U.S. 398 (1939). Agreeing to adjudicate the dispute over the decedent's domicile in the nature of interpleader, the Court declared that even though the state courts had not yet reduced the estate's liability to a final judgment and even though the estate funds had not yet actually been exhausted, there was still a justiciable "case or controversy." The Court appointed a Special Master to determine the decedent's domicile at the time of death.

54. Until the estate has been exhausted only the administrators and beneficiaries of the estate have an interest at stake. See California v. Texas I, 437 U.S. 601, 610 (1978) (Stewart, J., concurring); Massachusetts v. Missouri, 308 U.S. 1, 16, 18 (1939).

Today the chances of an estate actually being exhausted are especially slim. An increasing number of states, including California, levy only a "pick-up tax," that takes advantage of the credit for state estate taxes provided by I.R.C. § 2011 (1984). All State Compendiums, INHER. Esr. \& GIFT TAX REP. (CCH) 70,101-70,633. Assuming a top federal rate of 55\%, the $\S 2011$ credit permits a state to "pick-up" a tax worth $16 \%$ of the taxable estate. In effect, the federal government levies only a $39 \%$ tax, while the state levies a $16 \%$ tax. Once this credit is exhausted, additional state taxes raise the effective tax rate above 55\%. But as long as each state tax does not exceed 16\% (most state taxes do not), an additional 3 states still would have to levy taxes before the estate was exhausted.

55. See California v. Texas II, 457 U.S. 164, 168 (1982). The Supreme Court looks to two factors when it decides whether or not to hear a case under its original jurisdiction:

A determination that this Court has original jurisdiction over a case, of course, does not require us to exercise that jurisdiction. We have imposed prudential and equitable limitations upon the exercise of our original jurisdiction. ...

"And the question of what is appropriate [to determine jurisdiction] concerns, of course, the seriousness and the dignity of the claim; yet beyond that it necessarily involves the availability of another forum where there is jurisdiction over the named parties, where the issues tendered may be litigated, and where appropriate relief may be had." 
The requirement of ripeness poses an additional obstacle: Until all the claiming states have rendered final judgments that the decedent was domiciled within each of their respective borders at the time of death, assessed the taxes owed, and found the assets of the estate inadequate to pay the taxes, the claim may be too speculative to be heard by the Supreme Court. ${ }^{\text {s8 }}$

In summary, both state and lower federal courts lack the power to provide adequate remedies for the problem of multiple taxation on the basis of domicile. State courts have no power to assert jurisdiction over other states or to render judgments enforceable in other state courts. The Eleventh Amendment expressly prohibits federal courts from hearing suits brought against sovereign states. Even the remedy which the Supreme Court may provide is inadequate-only rarely do the preconditions necessary to seek adjudication under the Court's original jurisdiction occur. One must look elsewhere to address the multiple taxation problem caused by multiple findings of domicile.

\section{Moving Toward a New Due Process Analysis}

Despite its uneasiness with multiple taxation of intangible estates, the Aldrich Court feared to do 'violence to the words 'due process' by drawing lines where the Fourteenth Amendment fails to draw them." Aldrich Court realized that the attempt to impose due process limits on intangible estates by analogy to real and tangible estates was not only anachronistic and unworkable, but also insensitive to basic federalism concerns. As one dissenting Justice noted, although due process requires that states possess a nexus that justifies the exercise of taxation powers, due process does not define what that nexus should be. ${ }^{58}$ Only twice has the taxing nexus been so obvious that the Court has declared that only that one nexus and no other nexus could be a permissible one: Only the state that physically protects real estate renders a taxable benefit. Other benefits a state might confer upon real estate are deemed insubstantial, if not illusory. ${ }^{59}$ The same applies to tangible property. ${ }^{60}$

457 U.S. at 168 (quoting Illinois v. City of Milwaukee, 406 U.S. 91, 93-94 (1972) (citations omitted)).

56. See California v. Texas II, 457 U.S. at 170 (Powell, J., joined by Marshall, Rehnquist, \& Stevens, JJ., dissenting) ("The mere possibility of inconsistent state determinations of domicile, resulting in a still more remote possibility of the estate's being insufficient to satisfy the competing claims, simply does not give rise to a case or controversy in the constitutional sense."); see also California v. Texas I, 437 U.S. 601, 611, 614-15 (1978) (Stewart, J., joined by Powell \& Stevens, JJ., concurring) (same). Under this reasoning, the precedent-setting case of Texas v. Florida, discussed supra note 53, should not have been heard by the Supreme Court in the first place.

57. State Tax Comm'n v. Aldrich, 316 U.S. 174, 179 (1942).

58. Id. at 201 (Jackson, J., dissenting).

59. Curry v. McCanless, 307 U.S. 357, 364-65 (1939). 
The taxation of real estate and chattels, however, is an exception to the norm of allowing the states to specify the taxable benefit. ${ }^{61}$ As other areas of law indicate, the due process clause does not mandate specific contacts. It requires only that there be a rational connection between the state and the activity governed that justifies the exercise of state sovereign power. ${ }^{62}$ Nonetheless, even though the Court has found that due process does not require one particular nexus in the taxation of intangible estates as it does in the taxation of real and tangible estates, ${ }^{\mathbf{6 3}}$ there are due process limits on taxation which the Court has failed to acknowledge in its most recent estate taxation cases. ${ }^{64}$ The Court has not followed its own lead: In the choice of law and adjudicative jurisdiction areas, the Court has brought about an almost complete restructuring of due process analysis. The move has been one away from the old doctrines that had effectively determined state law to analyses that look to whether the assertion of state power is justified by certain minimum contacts or connections. ${ }^{65}$ Moreover, underlying much of the evolving due process doctrine is a more focused sensitiv-

60. Id.

61. Bittker, supra note 4, argues persuasively that the Constitution should not specify the benefit conferred for tangible property either. Comparing tangibles to intangibles, Bittker finds that those benefits conferred by states upon tangibles cannot any more easily be allocated to one state than can benefits conferred upon intangibles. Moreover, while the rule of situs for real property may be too deeply rooted in common law simply to overrule, and the rationale given in Curry v. McCanless, 307 U.S. 357 (1939), that only the state of situs can render a meaningful benefit, really does hold, the same is not true for tangibles. As with intangibles, the due process clause should not be read to preclude taxation of tangible property by more than one state.

62. The due process clause requires "minimal contacts" before a state court can assert personal jurisdiction over a defendant. Hanson v. Denckla, 357 U.S. 235, 251 (1958) (citing International Shoe Co. v. Washington, 326 U.S. 310,319 (1945)). Likewise, due process requires significant contacts or aggregation of interests before a state court may apply forum law. Allstate Ins. Co. v. Hague, 449 U.S. 302,308 (1981). Due process imposes a parallel restraint on state taxation by requiring that a taxing state possess a nexus that justifies the tax it levies. Justice Powell quotes an oft-repeated definition of the limits that due process places on state taxing powers:

"Th[e] test is whether property was taken without due process of law, or, if paraphrase we must, whether the taxing power exerted by the state bears fiscal relation to protection, opportunities and benefits given by the state. The simple but controlling question is whether the state has given anything for which it can ask return."

Cory v. White, 457 U.S. 85, 98 (1982) (Powell, J., dissenting) (citations omitted) (quoting Wisconsin v. J.C. Penney Co., 311 U.S. 435, 444 (1940)).

63. See supra text accompanying notes 16-24 \& notes $3,4,5,7$ \& 18.

64. See, e.g., California v. Texas II, 457 U.S. 164, 165 (1982) (California's motion seeking Court's original jurisdiction granted); Cory v. White, 457 U.S. 85, 91 (1982) (double taxation of intangible estates on the basis of domicile does not violate the Constitution).

65. For literature discussing the evolution of due process limits in the choice of law area, see Kirgis, The Roles of Due Process and Full Faith and Credit in Choice of Law, 62 CoRnell. L. Rev. 94 (1976); Martin, Constitutional Limitations on Choice of Law, 61 CoRnell L. Rev. 185 (1976); Reese, Legislative Jurisdiction, 78 Colum. L. REv. 1587 (1978). For articles discussing adjudicative jurisdiction, see Brilmayer, How Contacts Count: Due Process Limitations on State Court Jurisdiction, 1980 Sup. CT. REv. 77; Hazard, A General Theory of State-Court Jurisdiction, 1965 SuP. CT. Rev. 241; Kurland, The Supreme Court, the Due Process Clause and the In Personam Jurisdiction of State Courts-From Pennoyer to Denckla: A Review, 25 U. CHI. L. Rev. 569 (1958). 
ity towards state sovereignty and towards the powers states need to remain viable governing units within a federal structure. ${ }^{68}$

This concern shows itself clearly in the corporate income tax area. The Supreme Court has been a somewhat unwilling and definitely cautious final arbiter in disputes concerning state corporate taxation. ${ }^{87}$ The Court protests that the only body which should so intrude upon state powers is Congress. ${ }^{68}$ Despite these repeated declarations, Congress has been decidedly chary of exercising its legislative powers. ${ }^{69}$ The Tax Injunction Act ${ }^{70}$ similarly embodies the deference that has traditionally been accorded to state taxing powers. The Act severely restricts federal court jurisdiction over claims concerning state taxes and "has its roots in equity practice, in

66. See Hazard, supra note 65 at 245-248; Kurland, supra note 65 at 569; see also Kirgis, supra note 65 (arguing that Full Faith and Credit clause better suited to address such state sovereignty and federalism concerns).

67. The Court most recently declared that it will "if reasonably possible, defer to the judgment of state courts in deciding whether a particular set of activities constitutes a "unitary business." Container Corp. of Am. v. Franchise Tax Bd., 103 S. Ct. 2933, 2945 (1983). See also 1 J. Hellerstein, State Taxation: Corporate Income and Franchise Taxes 338-89 (historical and analytical account of Supreme Court's reluctance to strike down state corporate income tax laws).

68. See, e.g., Moorman Mfg. Co. v. Bair, where the Court stated:

[T] he freedom of the States to formulate independent policy in this area may have to yield to an overriding national interest in uniformity .... It is clear that the legislative power granted to Congress by the Commerce Clause of the Constitution would amply justify the enactment of legislation requiring all States to adhere to uniform rules for the division of income. It is to that body, and not this Court, that the Constitution has committed such policy decisions.

437 U.S. 267,280 (1978).

69. Despite its powers under the commerce clause, Congress had not, prior to 1959 , legislated in the state corporate income tax area. Since then it has enacted six pieces of legislation-all quite narrow in scope. See Hellerstein, State Income Taxation of Multijurisdictional Corporations: Reflections on Mobil, Exxon, and H.R. 5076, 79 Mich. L. Rev. 113, 113-15 (1980). Instead, the states have largely been left to regulate themselves. Many states have adopted uniform statutes or adopted the Multistate Tax Compact (1967). Because estate taxes do not fall within the scope of the commerce clause, it is also at least questionable whether the Constitution has authorized Congress to legislate in the state estate tax area, as two commentators have suggested that it should. See Comment, How Far Will Multi-State Death Taxation Go?, 1 VAND. L. REv. 93, 105 n.46 (1947); Note, Determination of Domicil for Inheritance Tax Purposes by an Original Action in the United States Supreme Court, 46 Yale L.J. 1235, 1242 (1937). Although the due process clause of the Fourteenth Amendment authorizes Congress to enforce the commands of the Fourteenth and Fifteenth Amendment, it is not clear that the grant of power would extend to those concerns not having to do with civil rights. See L. Tribe, American Constitutional. Law \$§ 5-14, 5-20 (1978). Moreover, the Supreme Court has engaged in fierce debate as to the scope of Congressional power vis-à-vis the states. See E.E.O.C. v. Wyoming, 103 S. Ct. 1054, 1060 (1983) (sovereign immunity as functional doctrine to ensure states' independent existence within federal structure). Contra, Garcia v. San Antonio Metropolitan Transit Auth., 53 U.S.L.W. 4135 (U.S. Feb. 19, 1985) (overruling National League of Cities v. Usery, 426 U.S. 833 (1976)). There is little, if any, literature exploring the interesting question of whether Congress could legislate in this area, i.e. enact a uniform definition of domicile as a matter of federal law.

70. 28 U.S.C. $\$ 1341$ (1982). The Act provides that "[t]he district courts shall not enjoin, suspend or restrain the assessment, levy or collection of any tax under State law where a plain, speedy, and efficient remedy may be had in the courts of such State." Id. 
principles of federalism, and in recognition of the imperative need of a State to administer its own fiscal operations."

The original attempts to use the due process clause to prevent the multiple taxation of estates did not take a balanced approach towards the sovereign rights of both the state and federal governments. Rather, by requiring a specific nexus, the Court effectively dictated state law. Yet in overruling the constitutional requirement of domicile, the Aldrich Court went too far to accommodate state powers. States' rights need not be unlimited. The due process analysis which has developed in the corporate tax area suggests an alternative, more balanced approach.

\section{Due Process Limits on State Corporate Income Taxation Should be Applied to State Estate Taxation}

In the corporate tax area, due process requires first that the levying state confer a benefit that justifies the tax levied, and second that the tax be rationally related to taxing values within the state. The latter requirement reflects an implicit bar against double taxation.

\section{A. Due Process Does Not Permit the Abuse of a Nexus}

Just as the Supreme Court has refused to mandate the basis on which a state may levy an estate tax on intangibles, ${ }^{72}$ the Supreme Court has refused to mandate the basis on which a state may levy a corporate income

71. Tully v. Griffin, Inc., 429 U.S. 68, 73 (1976). In Rosewell v. LaSalle Nat'I Bank, 450 U.S. 503 (1981), the Court explained:

Finally, we note that the reasons supporting federal non-interference are just as compelling

today as they were in in 1937 . If federal injunctive relief were available,

"state tax administration might be thrown into disarray, and taxpayers might escape the ordinary procedural requirements imposed by state law. During the pendency of the federal suit the collection of revenue under the challenged law might be obstructed, with consequent damage to the State's budget, and perhaps a shift to the State of the risk of taxpayer insolvency."

Id. at 527 (quoting Perez v. Ledesma, 401 U.S. 82, $128 \mathrm{n} .17$ (1971) (Brennan, J., concurring in part and dissenting in part)). Of the recent cases construing the scope of the Tax Injunction Act, Fair Assessment in Real Estate Ass'n. v. McNary, 454 U.S. 100 (1981), announces most strongly the federalism and state sovereignty arguments barring federal court intervention in the state tax area. Indeed, the opinion looks beyond the Tax Injunction Act to general federalism and comity restraints:

"The scrupulous regard for the rightful independence of state governments which should at all

times actuate the federal courts, and a proper reluctance to interfere by injunction with their

fiscal operations, require that such relief should be denied in every case where the asserted federal right may be preserved without it."

Id. at 111 (quoting Great Lakes Dredge \& Dock Co. v. Huffman, 319 U.S. 293, 298 (1943), which quoted Matthews v. Rodgers, 284 U.S. 521, 525 (1932)). Admittedly, the Tax Injunction Act and even Fair Assessment speak only to the restraint which should be exercised by the lower federal courts, and not to the restraints that should be exercised by the Supreme Court, or by Congress. Nonetheless, the Act indicates that, if it is at all possible, restraint should be exercised. See also supra notes 67-69 (describing restraints on Supreme Court and Congress).

72. State Tax Comm'n v. Aldrich, 316 U.S. 174, 181-82 (1942). 
tax. $^{73}$ A state may levy a corporate income tax on the basis of corporate privilege or unitary business or any other nexus it shows as qualifying under due process standards. ${ }^{74}$ Those states which use a separate accounting method $^{75}$ to measure the income which a corporation generates within its borders levy a tax only if the corporation conducts a business within the state and avails itself of corporate privilege. ${ }^{76}$ Other states use the unitary business tax method, ${ }^{77}$ levying a tax only if the corporation conducts a unitary business within the state. ${ }^{78}$ Because the various taxes are all based on a minimal connection or nexus between the taxing state and the activities taxed, all are constitutional methods. ${ }^{79}$ Due process does not, except as regards situs of real property or tangible personalty, declare that one method is the constitutionally mandated one. ${ }^{\mathbf{8 0}}$

73. See, e.g., Wisconsin v. J.C. Penney Co., 311 U.S. 435, 444 (1940). Justice Frankfurter declared:

The Constitution is not a formulary. It does not demand of states strict observance of rigid categories nor precision of technical phrasing in their exercise of the most basic power of government, that of taxation .... A state is free to pursue its own fiscal policies, unembarrassed by the Constitution, if by practical operation of a tax the state has exerted its powers in relation to opportunities which it has given, to protection which it has afforded, to benefits which it has conferred by the fact of being an orderly, civilized society.

Id. at 444. See also Container Corp. of Am. v. Franchise Tax Bd., 103 S. Ct. 2933, 2941 (1983) (there must be both minimal connection or nexus between business activities and taxing state, and rational relationship between income attributed to state and intrastate value of enterprise); Mobil Oil Corp. v. Commissioner of Taxes, 445 U.S. 425, 436-37 (1980) (same); Exxon Corp. v. Department of Revenue, 447 U.S. 207, 219-20 (1980) (same).

74. Moorman Mfg. Co. v. Bair, 437 U.S. 267, 272-73 (1978); see supra note 73.

75. There are two types of corporate income taxes: (1) excise taxes on doing business or owning property within the state and (2) taxes on net income derived from or attributable to business within the state. J. Hellerstein, supra note 67, at 263-64. The latter type of tax, the corporate income tax, is levied by states in two different ways. If a business is entirely intra-state or the income flowing in from a business is clearly allocable to business within the state, the state taxing authorities will usually use a separate accounting basis to tax corporate income. "Separate accounting is a technique of carving out of the overall business of the taxpayer the activities taking place, the property employed in, and the income derived from, sources within a single State . . . " Id. at 323.

76. Id.

77. As businesses have increasingly become nationwide enterprises, it has become more difficult to break down corporate earnings state by state with any accuracy. Id. at 300. Most state taxing authorities now use what is called a unitary business tax method to tax corporate income. Many states have adopted the UnIf. Division of Income for TAX Purposes ACT, 7A U.L.A. 91 (1978) ("UDITPA"). J. Hellerstein, supra note 67, at 333-35. Defining unitary business, the Supreme Court stated:

The "unitary business" technique involves calculating a corporate taxpayer's net income on the basis of all phases of a single enterprise (e.g., production of components, assembly, packing, distribution, sales), even if located outside the jurisdiction. The portion of that income attributable to activities within the taxing State is then determined by means of an apportionment formula.

United States Steel Corp. v. MultiState Tax Comm'n, 434 U.S. 452, 473 n. 25 (1978). The typical state apportions the percentage which it is entitled to tax on the basis of three factors: (1) property within the state as a percentage of total property owned; (2) payroll within the state as a percentage of total payroll; and (3) sales within the state as a percentage of total sales. J. HellersteIN, supra note 67 , at $330-38$.

78. See Mobil Oil Corp. v. Commissioner of Taxes, 445 U.S. 425, 437 (1980).

79. See Moorman Mfg. Co. v. Bair, 437 U.S. 267, 272-73 (1978).

80. See supra text accompanying notes $57-62$ and $72-80$. 
Even though the due process clause does not mandate the use of a particular nexus, neither does it permit the abuse of a nexus. The nexus ensures that there is some minimal connection between the business activity taxed and the state. ${ }^{81}$ The state cannot arbitrarily define the nexus and thereby rob the nexus of its constitutional function. A state may not, for example, declare that it is using the unitary business principle to determine what parts of the corporate income shall form the base to be apportioned, and then include all of a corporation's income, including nonunitary income, as part of the unitary business income. ${ }^{\mathbf{8 2}}$

A similar analysis fits easily within the estate taxation context, and would provide both coherence and fairness. Due process does not mandate that a state levy an estate tax only on the basis of domicile, but once a state has declared that its nexus is domicile, it may not then simply define domicile in such a way as to enable itself to tax estates regardless of actual domicile-regardless of the professed nexus. Due process should not permit states to overreach by claiming domicile when the decedent was not domiciled within the state at the time of death.

Adopting this approach would not require the Supreme Court to set forth its own definition of domicile. In the area of corporate taxation, the Court has not set forth its own definition of what constitutes a unitary business. ${ }^{83}$ Rather, when a corporation has made a colorable claim that the state's definition of a unitary business effectively renders the concept a nullity, the Court conducts a case-by-case review. ${ }^{84}$ Even though the Court has refused to advance a federal definition of what constitutes a unitary business, it is clear that there are constitutional components that form a federal floor on which the definition must rest. The state's definition of what constitutes a unitary business must contain at least those components that make the unitary business principle an acceptable nexus

81. See Norfolk \& W. Ry. Co. v. Missouri State Tax Comm'n, 390 U.S. 317, 324-25 (1968) ("[T]he Court has insisted for many years that a State is not entitled to tax tangible or intangible property that is unconnected with the State . . . . [b]ecause it denies to the taxpayer the process that is his due.") (citations omitted) (citing Fargo v. Hart, 193 U.S. 490, 499-500 (1904)); J. HeLLERSTEIN, supra note 67 , at $412-34$.

82. The Supreme Court has agreed to hear cases where a corporation has alleged that a state was including non-unitary income within its unitary business income. See ASARCO v. Idaho State Tax Comm'n, 458 U.S. 307 (1982) (Idaho could not constitutionally include income having no connection with Idaho as part of apportionable unitary business income); F.W. Woolworth Co. v. Taxation \& Revenue Dep't, 458 U.S. 354 (1982) (unrelated business income not part of apportionable unitary business income); Mobil Oil Corp. v. Commissioner of Taxes, 445 U.S. 425 (1980) (intercorporate dividend income part of apportionable unitary business income); Exxon Corp. v. Department of Revenue, 447 U.S. 207 (1980) (because marketing operations part of larger unitary business, income attributable to marketing operations part of apportionable unitary business income).

83. See Container Corp. of Am. v. Franchise Tax Bd., 103 S. Ct. 2933, 2941 (1983); Moorman $M f g ., 437$ U.S. at $279-80$.

84. See Container Corp., 103 S. Ct. at 2945-46. 
under the due process clause. ${ }^{85}$ The federal question which the Gourt addresses in its unitary business cases is whether the state is overreaching through its definition of the nexus, thus rendering the nexus a nullity, and the taxes levied a violation of due process. ${ }^{86}$

A parallel federal question as to whether a state has overreached in its definition of domicile would give the Supreme Court jurisdiction in its appellate role. ${ }^{87}$ To resolve the question, the estate administrators would bring their suits in the relevant state courts, and then request Supreme Court review if those state courts denied the relief sought. The administrators would have a right of appeal to the Supreme Court if they charged that a state's definition of domicile on its face violates due process. If the estate administrators charged that the application of the state's definition of domicile violates due process, then they would have to petition for a writ of certiorari. ${ }^{88}$ In either case, the administrators would have a remedy at law-one which does not depend on the rare double contingency that the taxes are actually levied and that there is not enough money to pay them.

As an example, the administators of the Howard Hughes estate have a colorable claim that the state of Texas overreached constitutional limits through its definition of domicile. To support their motions for and against leave to file a complaint under the Supreme Court's original jurisdiction, both California ${ }^{89}$ and $\mathrm{Texas}^{80}$ set forth facts supporting the argument that Hughes had abandoned his domicile in Texas sometime during

85. See Woolworth, 458 U.S. at 363-64.

86. The Court has held that defining a unitary business as constituting all the income that "adds to the riches of the corporation" trivializes the due process limits on state taxing powers. Woolworth, 458 U.S. at 363 (quoting Wallace v. Hines, 253 U.S. 66, 70 (1920)). In another case, the Court declared that defining unitary business by corporate purpose rather than underlying economic reality "would destroy the concept." ASARCO, 458 U.S. at 326.

87. Contrary to Justice Powell's suggestion in Cory v. White, 457 U.S. 85, 101 (1982) (Powell, J., joined by Marshall \& Stevens, JJ., dissenting), seeking adjudication in a federal district court would be highly problematic. Even though there are federal questions at stake, the Tax Injunction Act, 28 U.S.C. $\$ 1341$ (1982), denies the federal district courts jurisdiction to restrain a state tax in all but the exceptional case when there is no other remedy available. The Tax Injunction Act has kept all of the corporate income tax cases out of federal district courts and would probably do the same for estate taxation cases. Ironically, when there is no federal question, the Tax Injunction Act would not bar an interpleader action in a federal district court since no other remedy is available. The Eleventh Amendment, however, bars such a suit. One can circumvent the Eleventh Amendment only by alleging a constitutional violation, but once one has alleged a constitutional violation there is a federal question giving rise to Supreme Court review. Once Supreme Court review is available, the Tax Injunction Act applies, and bars an interpleader action.

88. Supreme Court review would also enable estate administrators to raise another, perhaps more classic, due process violation. Where the state has found domicile without the authority of state law and inconsistently with past state precedent, the Court may strike down that finding of domicile and declare that it will not allow the adequate state grounds doctrine to nullify due process limits. See discussion supra note 29.

89. Motion for Leave to File Complaint and Memorandum in Support of Motion for Leave to File Complaint, California v. Texas I, 437 U.S. 601 (1978) [hereinafter referred to as Memorandum in Support].

90. On Mation For Leave to File Complaint: Brief in Opposition, California v. Texas I, 437 U.S. 
his twenties. The California brief states that after Howard Hughes moved to California at the age of twenty, he did not return to Texas. Though he made self-serving statements that he did intend to return to Texas, he had arguably abandoned his Texas domicile and acquired a new domicile in California. ${ }^{81}$ The administrators could charge that the Texas state law on its face, or in its application, trivializes due process limits. By defining domicile in a way that enables it to claim that any person who is born within its borders, regardless of subsequent actions, remains a domiciliary of Texas, Texas law renders the concept and constitutional function of domicile a nullity. Presented with such an argument, the Supreme Court could decide that Texas had overreached itself in defining the nexus, and declare that only Galifornia may levy an estate tax on the Howard Hughes estate.

Due process limits on overreaching will not, however, resolve all the problems of multiple taxation. These limits will not address the situation where the two disputing states each have definitions of domicile that meet the federal floor, and have applied the definitions consistently. Nor will such limits resolve a dispute in which the determination of domicile is genuinely difficult, or one in which one of the states has made a mistaken finding of fact. The words spoken by the Court in Worcestor County $v$. Riley will still hold true: "[T]he Constitution of the United States does not guarantee that the decisions of state courts shall be free from error."

601 (1978) [hereinafter referred to as Brief in Opposition].

91. The Memorandum in Support for California states that Howard Hughes was born in Texas in 1905 and lived there for 20 years. He then moved to California and lived at the Beverly Hills Hotel in Los Angeles for the following 40 years until 1966. After leaving Texas in 1926, Hughes returned only for brief, occasional visits, but made apparently self-serving statements that he was still domiciled in Texas and claimed a mailing address there. While in California he developed "substantial new business interests and investments, including film production, aviation and aircraft manufacture." Memorandum in Support, supra note 89, at 7-8. The Brief in Opposition for Texas concedes that beginning in 1929 Hughes spent the majority of his time in California until 1966. During this period, he paid California taxes at the resident rate even though he claimed nonresidency on his California income tax returns. The Texas brief does not say that he paid any income taxes to Texas during this time, or afterwards. Hughes paid only a Texas poll tax until 1952. Brief in Opposition, supra note 90, at 2-5. At least on the basis of these facts, it seems quite clear that Howard Hughes gave up his domicile of origin for a new domicile of choice-California. Even though Hughes never bought a home in California and never developed the normal intimacies that one associates with making a place one's home, he did leave Texas. If he intended to return to Texas for any length of time, he never did so during his lifetime. Nor did he pay income taxes to Texas after 1926. On the contrary, Hughes lived in California for 40 years, and while he traveled frequently, until 1966 he always returned to the Beverly Hills Hotel. The state of California taxed Hughes as a domiciliary, and though he did go through the formality of filing a nonresident return, he never protested. It has been oft-repeated "that 'a man's home is where he makes it, not where he would like to have it.' It might also be said that 'a man's domicile is where the law fixes it, not where he tries to put it." " Tweed \& Sargent, Death and Taxes Are Certain-But What of Domicile, 53 Harv. L. REv. 68, 84 (1939).

92. Worcester County Trust Co. v. Riley, 302 U.S. 292, 299 (1937) (citations omitted). 


\section{B. Apportionment-The Implicit Bar Against Double Taxation}

Beyond the requirement that there be a nexus, due process mandates that "the income attributed to the State for tax purposes must be rationally related to "values connected with the taxing state."'93 States sometimes use a separate accounting method to measure the income a corporation generates within its borders. Separate accounting fulfills the due process rational relationship requirement by taxing only the income generated within the state. ${ }^{94}$ States also use the unitary business tax method. Because the unitary business principle allows several states to levy a tax on the same income, states use an apportionment formula to ensure that the tax is rationally related to income generated within the state. ${ }^{95}$

The Court, however, has repeatedly refused to inject itself into the debate as to which apportionment formulas are the most accurate and most fair ways to tax corporate income. ${ }^{96}$ As long as the formula of apportionment which the state chooses is "rationally related" to the values being taxed, states may use any formula they wish. Thus the Court has approved the use of a world-wide unitary business formula with three factors for apportionment, ${ }^{97}$ a one factor formula to apportion income earned only within the United States, ${ }^{98}$ and also a three factor formula apportioning United States income. ${ }^{99}$ There may be some overlap between the taxes which results in the slight overtaxation of a corporation which does business in several states, but such inaccuracies are considered an inevitable result of the uncertainties of measuring such a tax, and not worthy of judicial intervention. ${ }^{100}$

93. Moorman Mfg. Co. v. Bair, 437 U.S. 267, 273 (1978) (quoting Norfolk \& W. Ry. Co. v. Missouri State Tax Comm'n, 390 U.S. 317, 325 (1968)).

94. See supra note 75 .

95. See United States Steel Corp. v. MultiState Tax Comm'n, 434 U.S. 452 (1977), where the Court explained: "Taxable income deemed apportionable is that which is not considered to have its source totally within one State. It is distributed by means of an apportionment formula among the States in which the multistate business operates." Id. at 474 n.27.

96. Moorman $M f g ., 437$ U.S. at 278-80.

97. See, e.g., Container Corp. of Am. v. Franchise Tax Bd., 103 S. Ct. 2933, 2956-57 (1983) (upholding California statute apportioning income derived from world-wide unitary business rather than from United States unitary business).

98. See, e.g., Moorman Mfg., 437 U.S. at 281 (upholding Iowa's use of one factor apportionment formula).

99. See, e.g., Container Corp., 103 S. Ct. at 2943 (declaring three factor apportionment formula a benchmark against which all other formulas measured).

100. In one case, the Court declared:

[The unitary business method,] unlike separate accounting, does not purport to identify the precise geographical source of a corporation's profits; rather it is employed as a rough approximation of a corporation's income that is reasonably related to the activities conducted within the taxing State .... Both [the one factor and the three factor formula] will occasionally over-reflect or under-reflect income attributable to the taxing State. Yet despite this imprecision, the Court has refused to impose strict constitutional restraints on a State's selection of a particular formula.

Moorman Mfg. Co. v. Bair, 437 U.S. 267, 273 (1978). 
Yet due process is not infinitely elastic. Once the state has properly defined the nexus, the formula that the state uses to levy on the basis of that nexus must be both fair and rationally related to taxing values within the state. ${ }^{101}$ In evaluating one state's corporate taxation statutes, the Court declared: "The first, and again obvious, component of fairness in an apportionment formula is what might be called internal consistency-that is the formula must be such that, if applied by every jurisdiction, it would result in no more than all of the unitary business's income being taxed." ${ }^{102}$ A state's corporate income tax formula may not result in an inevitable overtaxation. For instance, a formula whereby a state apportions all of the corporation's sales revenue, wherever earned, to itself, violates due process. ${ }^{103}$ If the formula were applied by every jurisdiction, and the corporation did business in five states, the other four states would also apportion all of the sales revenue to themselves, and the corporation would be taxed on $500 \%$ of its unitary business's sales revenue. Extreme overtaxation, akin to double taxation, violates the due process requirement of fairness.

Stemming from the same concern that the tax be rationally related to income earned within a state, the Court then declared: "The second and more difficult requirement is what might be called external consistency - the factor or factors used in the apportionment formula must actually reflect a reasonable sense of how income is generated."104 A taxpayer challenging a state's corporate income tax formula bears the burden of proving "by clear and cogent evidence"10s that the apportionment formula attributes to the state an amount of income that is "out of all appropriate proportion to the business transacted ... in that State." ${ }^{3106}$ Should the taxpayer bear that burden, the Supreme Court will strike down the apportionment formula. In one early unitary business tax case, the Court struck down a formula because it attributed more than twice the income shown as being generated in the state, to that one state. ${ }^{107}$

Fairness under the due process clause prohibits gross overtaxation both by one state alone - one state alone may not double its tax by doubling the income attributable to itself - and by several states jointly. Thus, while due process does not bar double taxation on the basis of differing benefits

101. See Norfolk \& W. Ry. Co. v. Missouri State Tax Comm'n, 390 U.S. 317, 325 (1968); Hans Rees' Sons, Inc. v. North Carolina, 283 U.S. 123, 135-36 (1931).

102. Container Corp. of Am. v. Franchise Tax Bd., 103 S. Ct. 2933, 2942 (1983) (emphasis added).

103. Id.

104. Id.

105. Butler Bros. v. McColgan, 315 U.S. 501, 507 (1942) (citing Norfolk \& W. Ry. Co. v. North Carolina, 297 U.S. 682, 688 (1936)).

106. Hans Rees' Sons, Inc. v. North Carolina, 283 U.S. 123, 135 (1931).

107. Id. 
conferred to a single estate, it does bar double taxation or extreme overtaxation on the basis of the same benefit conferred.

Transplanted to the context of estate taxation, this standard of fairness forbids the gross overtaxation of an estate, whether by one state alone or by several states jointly. In the Howard Hughes case, each state's formula attributed $100 \%$ of the estate to each state, resulting in an inevitable taxation of $200 \%$ of the estate rather than just $100 \%$.

Admittedly, corporations have been hard pressed to show such dramatic overtaxation when they have challenged the state apportionment formulas. ${ }^{108}$ Such gross overtaxation, however, usually arises from the failure to split taxes, rather than from grossly distorted factor weighting. When states levy estate taxes the assumption is that since only one state will levy the tax there is no need to apportion the income. The same assumption underlies the separate accounting•method for the corporate income tax. The state levies a tax only on income generated within the state. ${ }^{109}$ When, however, more than one state levies a tax on the same income, as is the case with the unitary business tax, the state must then avoid overtaxation by apportioning the income. ${ }^{110}$

Hence, whenever more than one state has found that the decedent was domiciled within its borders, and each state has done so within the confines of its state laws and within the confines of the due process analysis, the Supreme Court should intervene to remedy this extraordinary situation. Due process demands that a tax be rationally related to the values being taxed, and double taxation of an intangible estate both violates the rational relation and fairness required by due process. The Court has several options: It could apportion the tax itself; or it could induce the states to split the taxes owed, as it did in the recent California $v$. Texas dispute. ${ }^{111}$ The Court could also make a single and binding determination of

108. Container Corp., 103 S. Ct. at 2949-50.

109. See J. Hellerstein, supra note 67, at 323-27.

110. See supra note 95.

111. The Court could also set forth an apportionment formula. There are two basic problems, however, with such an approach. The first is that such a formula might in effect dictate to states what factors should be used to determine domicile and how those factors should be weighed. The Court may prefer to refrain from such interference with state law. Second, it is not clear what sort of apportionment formula the Court could set forth. One possibility would be to allocate intangible property according to the tangible or real property located within the claiming states. But such an allocation seems both nonsensical and arbitrary. The amount of land that the deceased may have owned within a state bears no relationship to the benefits conferred upon the succession of intangible property. Another possibility would be to allocate according to the degree of connection the deceased had with the claiming states. The Court could look to factors such as length of residence, taxes paid, driver's license, voting records, local community activities, and other indicators of domiciliary intent. Yet such an inquiry involves such extensive fact-finding that the Court would actually make its decisions on an ad hoc basis, rather than on the basis of a formulary apportionment. For an article that discusses possible ways of sharing the tax, see Farage, Multiple Domicils and Multiple Inheritance Taxes-A Possible Solution, 9 Geo. Wash. L. Rev. 375 (1941). 
domicile, allowing only one state to levy the tax. If the claiming states have made legitimate findings of domicile under both their own state laws and under the due process federal floor, however, it would be fairest to encourage a settlement between the states, as was done in the Howard Hughes case.

\section{CoNCLUSION}

The history of property and estate taxation is "hardly one of settled consistency." $" 12$ Rather, it is a history that has created a constitutional due process analysis which is both distorted by anachronisms and at times grossly unfair. The Court should overrule Worcestor County v. Riley and recognize that the established due process limits on state power in the - corporate income tax area are equally applicable in the area of estate taxation. The states would retain their sovereign taxing powers and still have the discretion to choose how to levy their taxes. Their taxing machinery would remain undisturbed. Only in the case of extreme distortion of nexus, or in the extraordinary case where the determination of a decedent's domicile is truly difficult, need there be any Supreme Court intervention. The remedy will no longer depend on a double contingency giving rise to a dispute under the Court's original jurisdiction.

-Kathleen Leslie Roin

112. Cory v. White, 457 U.S. 85,97 n.6 (1982) (Powell, J., dissenting). 
